\title{
STRUCTURAL AND ELASTIC PROPERTIES OF FE-GE ALLOYS: AB INITIO STUDIES
}

\author{
M.A. Zagrebin ${ }^{1,2}$, M.V. Matyunina1, V.V. Sokolovskiy ${ }^{1,3}$, V.D. Buchelnikov ${ }^{1,3}$ \\ ${ }^{1}$ Chelyabinsk State University, Chelyabinsk, Russian Federation \\ ${ }^{2}$ South Ural State University, Chelyabinsk, Russian Federation \\ ${ }^{3}$ National University of Science and Technology "MISiS", Moscow, Russian Federation \\ E-mail:matunins.fam@mail.ru
}

In this paper, with the help of the density functional theory, the structural and elastic properties of $\mathrm{A2}, \mathrm{B2}, \mathrm{DO}_{3}$, and $\mathrm{L1}_{2}$ phases of $\mathrm{Fe}_{100-x} \mathrm{Ge}_{x}$ alloys $(12,5 \leq x$ $\leq \mathbf{2 8 , 1 2 5}$ at. $\%$ ) have been studied. The electronic and full ionic relaxations were used for the investigation of crystal structures. The concentration dependencies of the atomic volumes, structural phase transition temperatures, tetragonal and rhombohedral shear moduli have been calculated. We show that the atomic volume curves correlate with the sequence of phase transitions observed experimentally: $\mathrm{A2} \rightarrow \mathrm{B2} \rightarrow \mathrm{D0}_{3}(x \leq \mathbf{2 2}$ at. \% of Ge content). The structural phase transition temperatures increase with the Ge concentration. The calculated tetragonal moduli for the $\mathrm{DO}_{3}, \mathrm{A2}$, and $\mathrm{L1}_{2}$ structures decrease with the increasing of the Ge content, what agrees with the experimental results. The dependence of rhombohedral shear moduli as a function of Ge concentration does not change significantly with increasing Ge atoms. The $C_{44}$ is increased for the $\mathrm{DO}_{3}$ phase, while for $\mathrm{A2}$, $\mathrm{B} 2$, and $\mathrm{L1}_{2}$, it decreases.

Keywords: ab initio; crystal structure; phase transformations; elastic moduli.

\section{Introduction}

The discovery of large magnetostrictive strains in iron-gallium alloys in 1999 started the extensive study of rare-earth-free binary alloys based on $\alpha-\mathrm{Fe}[1,2]$. These alloys are promising materials for sensors and actuator applications. Among them, iron-gallium alloys are the most thoroughly investigated. The phase diagram of Fe-Ge alloys is very similar to Fe-Ga systems in the Fe-rich region [3]. Ga and $\mathrm{Ge}$ are $p$-elements that have a significant influence on electronic structures of binary compounds, which, in turn, determines their structural and magnetic properties. In both alloys, in the range of $\mathrm{Ga}(\mathrm{Ge})$ content up to 12 at. \%, the phase diagram is characterized by the existence of the disordered $\alpha$-phase (A2 structure). At these compositions, the values of magnetostriction $\left(\lambda_{100}\right)$ for Fe-Ga and Fe-Ge are similar and positive [1]. The further increase of Ga content up to 19 at. \% leads to the formation of mixing phase $\mathrm{D}_{3}+\mathrm{A} 2$ [4]. The magnetostriction of $\mathrm{Fe}_{81} \mathrm{Ga}_{19}$ reaches $340 \cdot 10^{-6}$ in slowly cooled samples. In the case of $\mathrm{Fe}_{81.5} \mathrm{Ge}_{18.5}, \mathrm{~B} 2$ and $\mathrm{D0}_{3}$ phases are observed [6], and $\lambda_{100}=-96 \cdot 10^{-6}$ [1]. In contrast to $\mathrm{Fe}-\mathrm{Ga}$ alloys, the properties of $\mathrm{Fe}-\mathrm{Ge}$ systems are not well investigated. Experimental studies of phase formation and transitions in alloys with Ge additives are presented in [5-13, etc.]. For Fe-Ge alloys in the phase region $x \leq 22$ at. $\%$, three types of the base-centered cubic $(b c c)$ structures with different ordering (fully disordered $\mathrm{A} 2$, partially ordered $\mathrm{B} 2$, and ordered $\mathrm{D}_{3}$ ) exist $[5,7,9,10,13]$. In the concentration range of Ge content $22 \leq x \leq 28$ at. \%, low temperature face-centered cubic $(f c c) \mathrm{L1}_{2}$ and high-temperature hexagonal $\mathrm{D} 0_{19}$ phases were also observed [5, 6, 8, 10-12]. The effect of the addition of Ge atoms on the elastic properties of Fe-Ge alloys is considered in $[1,14]$ : with the increase of $\mathrm{Ge}$ atoms in Fe lattice the tetragonal elastic modulus decreases.

The magnetic moments and Curie temperatures of $\mathrm{Fe}_{100-x} \mathrm{Ge}_{x}$ alloys were investigated theoretically in [15-18]. With adding of Ge atoms the total magnetic moment and Curie temperature reduced. Cao et al. [19] with the help of a full-potential-linearized augmented plane wave method studied the magnetostriction as a function of Ge concentration. They found that $\lambda_{100}$ increased linearly with $x$ up to 11 at. $\%$ and then decreased. In our recent work $[15,18]$ based on the total energy calculation of $\mathrm{Fe}_{100-x} \mathrm{Ge}_{x}$ alloys with different structures, the phase diagram as a function of $x$ was constructed. Nevertheless, the existing theoretical results are insufficient to understand the relation between phase transformations and magneto-elastic properties.

Therefore, this study aims to investigate the structural and elastic properties of cubic phases of $\mathrm{Fe}_{100-x} \mathrm{Ge}_{x}(12,5 \leq x \leq 28,125$ at. \%) alloys within different approaches to geometry optimization. The paper is organized as follows. Section 2 presents the details of $a b$ initio calculations. Section 3 contains 


\section{Физика}

the main results and discussion. Conclusions are provided at the end of the article (Section 4).

\section{Calculation details}

$A b$ initio calculations were performed by using the projector augmented wave (PAW) method implemented in the Vienna ab initio simulation package (VASP) [20,21]. The exchange-correlation effects were treated in generalized gradient approximation (Perdew-Burke-Ernzerhof formalization [22]). Pseudopotentials were taken for the following electronic configurations: $\operatorname{Fe}\left(3 p^{6} 3 d^{7} 4 s^{1}\right)$ and $\operatorname{Ge}\left(4 s^{2} 4 p^{2}\right)$. Kinetic energy cut-off was $450 \mathrm{eV}$, and kinetic energy cut-off for the augmentation charges was $800 \mathrm{eV}$. The Brillouin zone integration was performed by the Monkhorst-Pack scheme [23] with $8 \times 8 \times 8 k$-point sampling. The calculations were converged with the energy accuracy of $10^{-7} \mathrm{eV}$. The geometry optimization of 32-atom supercells was carried out with the help of electronic and ionic relaxation. In the case of electronic relaxation, the equilibrium lattice parameters $a_{0}$ were obtained from the dependency of total energy $E$ on the cell volume with a fitting to the Birch-Murnaghan equation of states. While the ionic optimization was fulfilled assuming that the cell shapes and ions degrees of freedom were fixed. The following phases in $\mathrm{Fe}_{100-x} \mathrm{Ge}_{x}(12,5 \leq x \leq 28,125$ at. \%) alloys, which were observed experimentally, were considered: A2 ( $\alpha$-Fe-type structure, space group $\operatorname{Im} \overline{3} m$ no. 229$)$, B2 (CsCl-type structure, space group $P m \overline{3} m$ no. 221$), \mathrm{D}_{3}\left(\mathrm{BiF}_{3}\right.$-type structure, space group $F m \overline{3} m$ no. 225$)$, and $\mathrm{L}_{2}\left(\mathrm{Cu}_{3} \mathrm{Au}\right.$-type structure, space group $P m \overline{3} m$ no. 221). To create off-stoichiometric compositions in 32-supercell for each structure, either Fe or Ge atoms were replaced by $\mathrm{Ge}$ or Fe on randomly chosen lattice sites, respectively. This allowed us to change the composition with the step of 3,125 at. \%.

After obtaining the lattice constants, we calculated the elastic moduli for cubic structures using strain tensors, which correspond to isotropic, orthorhombic, and monoclinic deformations. We assumed that the volume of the unit cell was constant, and the distortion parameter changed in the range of $\pm 3 \%$. Additional calculation details can be found in [24].

\section{Calculation results}

The calculated equilibrium lattice parameters $a_{0}$, total energies per atom $E_{0}$, and formation energies $E_{\text {form }}$ for electronic and ionic relaxation are presented in Table. The formation energy can be defined as a difference between the total energy per atom of an alloy and total energies per atom of its components in their equilibrium bulk structures:

$$
E_{\text {form }}=E_{0}\left(\mathrm{Fe}_{100-x} \mathrm{Ge}_{x}\right)-32\left[(100-x) E_{a t}^{\mathrm{Fe}}(\mathrm{Fe})+x E_{a t}^{\mathrm{Ge}}\right] / 100,
$$

where $E_{a t}^{\mathrm{Fe}(\mathrm{Ge})}$ is the total energy per atom of alloys components, $x$ is the Ge content concentration. For $\mathrm{A} 2, \mathrm{~B} 2, \mathrm{D}_{3}$, and $\mathrm{L}_{2}$ cubic structures, the lattice parameter increases with Ge content. In the case of B2 and $\mathrm{D}_{3}$ phases, the lattice constant decreases for systems with an excess of $\mathrm{Ge}(x>25$ at. \%). For the comparison, the experimentally obtained lattice constants are also included in Table. For both relaxations, the values of lattice parameters are in good agreement with each other and with experimental results. The difference between $a_{0}{ }^{e l}$ and $a_{0}{ }^{i o n}$ is less than $0,5 \%$, and between $a_{0}{ }^{e l}$ and $a_{0}{ }^{\text {exp }}$ is approximately $1 \%$. The differences between the obtained total energy values are negligible, and the $\mathrm{D}_{3}$ structure is energetically favorable for all considered Ge concentrations.

$\mathrm{B} 2, \mathrm{D}_{3}$, and $\mathrm{L}_{2}$ structures are stable because their formation energies are negative $\left(E_{\text {form }}<0\right)$. A2 phase is stable at Ge content $x<18$ at. \%. However, in the disordered A2 structure, the arrangement of atoms in the lattice has a significant effect on the ground state properties and formation energy, and we considered only one configuration.

Fig. 1(a) shows the atomic volume $V_{a}$ as a function of $\mathrm{Ge}$ concentration in the range of $12,5 \leq x \leq 28,125$ at. $\%$. The available experimental values $[6,9,10]$ for the A2 structure are also presented in Fig. 1(a). The closest to the experiment are A2 phase results obtained with electronic relaxation and Ge content of up to $x=21,875$ at. \%. In the range of $x>22$ at. \%, the experimental volume changes slightly, while the theoretical estimation continues to increase. The lowest and the largest $V_{a}$ are observed for the most stable phase $\mathrm{D}_{3}$ and $\mathrm{A} 2$ structure, respectively. The $V_{a}$ of the $\mathrm{B} 2$ structure is close to $\mathrm{D}_{3}$. Under the transition from disordered to ordered state, the unit-cell parameters decrease slightly and, therefore, the atomic volume also decreases [25-27]. The obtained dependencies of $V_{a}$ on Ge content correspond to the sequence of phase transitions observed experimentally [5, 13]: 
$\mathrm{A} 2 \rightarrow \mathrm{B} 2 \rightarrow \mathrm{D} 0_{3}\left(8 \leq x \leq 22\right.$ at. \%). The $f c c$ phase $\mathrm{L1}_{2}$ in the range of $21,875 \leq x \leq 28,125$ at. \% has a minimum of $V_{a}$ in stoichiometric composition $\mathrm{Fe}_{75} \mathrm{Ge}_{25}$, which is in agreement with the experimental data [11]. The $\mathrm{L}_{2}$ phase is experimentally observed in the narrow Ge concentration range $x \approx 22 \div 25,7$ at. $\%[5,11,28,29]$. Here, we simulated a wider range of concentrations for the $\mathrm{L}_{2}$ phase, since the minimal concentration step in the 32 -atoms supercell is 3,125 at. \% . Optimized lattice constant $a_{0}(\AA)$, total energy $E_{0}\left(\mathrm{eV} /\right.$ atom), and formation energy $E_{\text {form }}$ (meV/atom) of $\mathrm{Fe}_{100-x} \mathrm{Ge}_{x}$ alloys in comparison with experimental data $\left(a_{0}{ }^{\text {exp }}\right)$. The positive values of formation energy are bolded

\begin{tabular}{|c|c|c|c|c|c|c|c|c|}
\hline \multirow[t]{2}{*}{$x$} & \multirow[t]{2}{*}{ Phase } & \multicolumn{3}{|c|}{ Electronic relaxation } & \multicolumn{3}{|c|}{ Ionic relaxation } & \multirow{2}{*}{$a_{0}^{\exp }$} \\
\hline & & $a_{0}^{e l}$ & $E_{0}$ & $E_{\text {form }}$ & $a_{0}^{i o n}$ & $E_{0}$ & $E_{\text {form }}$ & \\
\hline \multirow[t]{3}{*}{12,5} & $\mathrm{~A} 2$ & 2,874 & $-7,803$ & $-12,845$ & 2,867 & $-7,802$ & $-11,566$ & $2,885(13,03 \text { at. } \%)^{1}$ \\
\hline & B2 & 2,865 & $-7,809$ & $-18,965$ & 2,857 & $-7,809$ & $-19,022$ & \\
\hline & $\mathrm{DO}_{3}$ & 5,72 & $-7,851$ & $-60,717$ & 5,707 & $-7,851$ & $-60,709$ & \\
\hline \multirow[t]{3}{*}{15,625} & $\mathrm{~A} 2$ & 2,879 & $-7,680$ & $-6,744$ & 2,873 & $-7,680$ & $-6,697$ & $\begin{array}{l}2,885(16,13 \text { at. } \%)^{1}, \\
2,891(14 \text { at. } \%)^{2}\end{array}$ \\
\hline & B2 & 2,865 & $-7,695$ & $-22,112$ & 2,862 & $-7,696$ & $-22,087$ & \\
\hline & $\mathrm{D}_{3}$ & 5,720 & $-7,743$ & $-69,712$ & 5,708 & $-7,743$ & $-69,665$ & \\
\hline \multirow[t]{3}{*}{18,75} & $\mathrm{~A} 2$ & 2,889 & $-7,556$ & 0,718 & 2,883 & $-7,556$ & $\mathbf{0 , 7 3 7}$ & $2,899(20 \text { at. } \%)^{2}$ \\
\hline & B2 & 2,870 & $-7,580$ & $-23,354$ & 2,863 & $-7,580$ & $-23,306$ & \\
\hline & $\mathrm{DO}_{3}$ & 5,722 & $-7,636$ & $-79,794$ & 5,709 & $-7,636$ & $-78,904$ & \\
\hline \multirow[t]{4}{*}{21,875} & A2 & 2,898 & $-7,418$ & 21,643 & 2,890 & $-7,418$ & 22,019 & $\begin{array}{l}2,902(22.5 \text { at. } \%)^{2} \\
2,885(21 \text { at. } \%)^{3}\end{array}$ \\
\hline & B2 & 2,868 & $-7,462$ & $-22,965$ & 2,860 & $-7,463$ & $-23,219$ & \\
\hline & $\mathrm{DO}_{3}$ & 5,725 & $-7,530$ & $-90,285$ & 5,711 & $-7,529$ & $-89,203$ & \\
\hline & $\mathrm{L} 1_{2}$ & 3,640 & $-7,505$ & $-65,941$ & 3,633 & $-7,505$ & $-65,358$ & \\
\hline \multirow[t]{4}{*}{25} & $\mathrm{~A} 2$ & 2,909 & $-7,275$ & 47,329 & 2,903 & $-7,275$ & 47,684 & $2,903(25 \text { at. } \%)^{2}$ \\
\hline & B2 & 2,867 & $-7,343$ & $-19,991$ & 2,861 & $-7,343$ & $-19,911$ & \\
\hline & $\mathrm{DO}_{3}$ & 5,720 & $-7,423$ & $-100,095$ & 5,707 & $-7,423$ & $\begin{array}{l}- \\
100,083\end{array}$ & \\
\hline & $\mathrm{L}_{2}$ & 3,638 & $-7,413$ & $-90,031$ & 3,629 & $-7,412$ & $-89,481$ & $3,665^{4}$ \\
\hline \multirow[t]{4}{*}{28,125} & $\mathrm{~A} 2$ & 2,920 & $-7,135$ & 70,431 & 2,914 & $-7,136$ & 70,408 & $2,901(27,5 \text { at. } \%)^{2}$ \\
\hline & B2 & 2,867 & $-7,218$ & $-12,121$ & 2,860 & $-7,218$ & $-12,141$ & \\
\hline & $\mathrm{D}_{3}$ & 5,716 & $-7,277$ & $-71,689$ & 5,707 & $-7,277$ & $-70,947$ & \\
\hline & $\mathrm{L}_{2}$ & 3,655 & $-7,247$ & $-41,225$ & 3,649 & $-7,247$ & $-41,201$ & $3,668^{4}(26,3$ at.\%) \\
\hline
\end{tabular}

${ }^{1}$ Data were taken from [6].

${ }^{2}$ Data were extrapolated from [10].

${ }^{3}$ Data were taken from [7].

${ }^{4}$ Data were taken from [11].
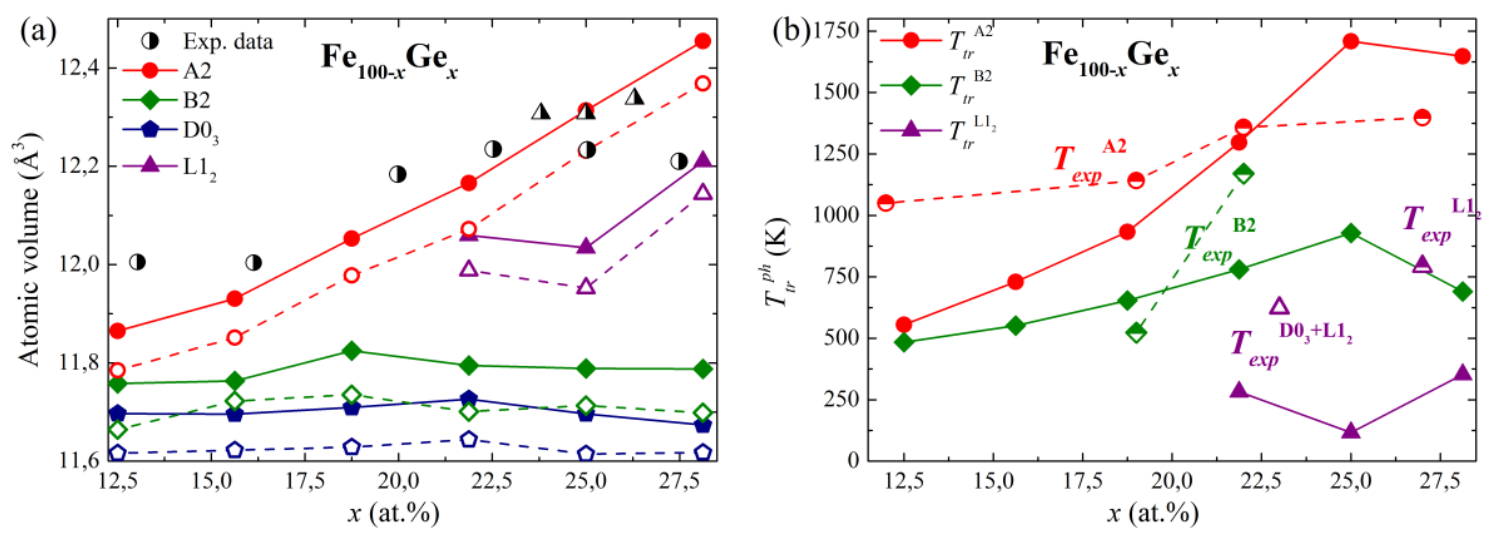

Fig. 1. Dependence of (a) $\mathrm{Fe}_{100-x} \mathrm{Ge}_{x}$ atomic volume $V_{a}$, and (b) calculated temperatures of structural phase transitions on Ge concentration, $x$. Atomic volumes $V_{a}(x)$ were obtained by two types of relaxations: electronic (filled symbols) and full ionic (open symbols). Experimental atomic volumes (half-filled symbols) for A2 (circles) and L1 (triangles) structures were taken from $[6,9-11]$. The experimental values of $T_{t r}$ were taken from $[8,11-13]$ 


\section{Физика}

Fig. 1 (b) presents the calculated temperatures of structural phase transitions $T_{t r}^{p h}$ as a function of Ge concentration and their comparison with the available experimental data [8, 11-13]. The estimations of $T_{t r}^{p h}$ can be obtained from $\Delta E \approx k_{B} T_{t r}^{p h}$, where $\Delta E=E_{0}-E_{\text {min }}, E_{\text {min }}$ is the energy of the most energetically favorable structure ( $\mathrm{DO}_{3}$ in this case), and $k_{B}$ is the Boltzmann constant. The structural phase transition temperature is the temperature, above which the corresponding phase exists. For all considered structures, $T_{t r}^{p h}$ values increase with Ge concentration. The slope of the theoretical $T_{t r}^{A 2}(x)$ curve is steeper than the experimental one. For $x>22$ at. \%, the experimental $T_{\text {exp }}^{\mathrm{A} 2}$ curve changes slightly, while the theoretical estimation of $T_{t r}^{\mathrm{A} 2}$ continues to increase up to 25 at. \% of Ge. For the B2 structure, the experimental $T_{\text {exp }}^{\mathrm{B} 2}$ curve increases more rapidly than the theoretical one. The pure structure $\mathrm{L} 1_{2}$ is experimentally observed at about 25 at. \% of Ge content (through the $\mathrm{D}_{19} \rightarrow \mathrm{L}_{2}$ transition). The range $22 \leq x \leq 27$ at. \% is characterized by different mixtures of the $\mathrm{B} 2, \mathrm{D}_{3}, \mathrm{D} 0_{19}$, and $\mathrm{L}_{2}$ phases $[5,8,13]$.
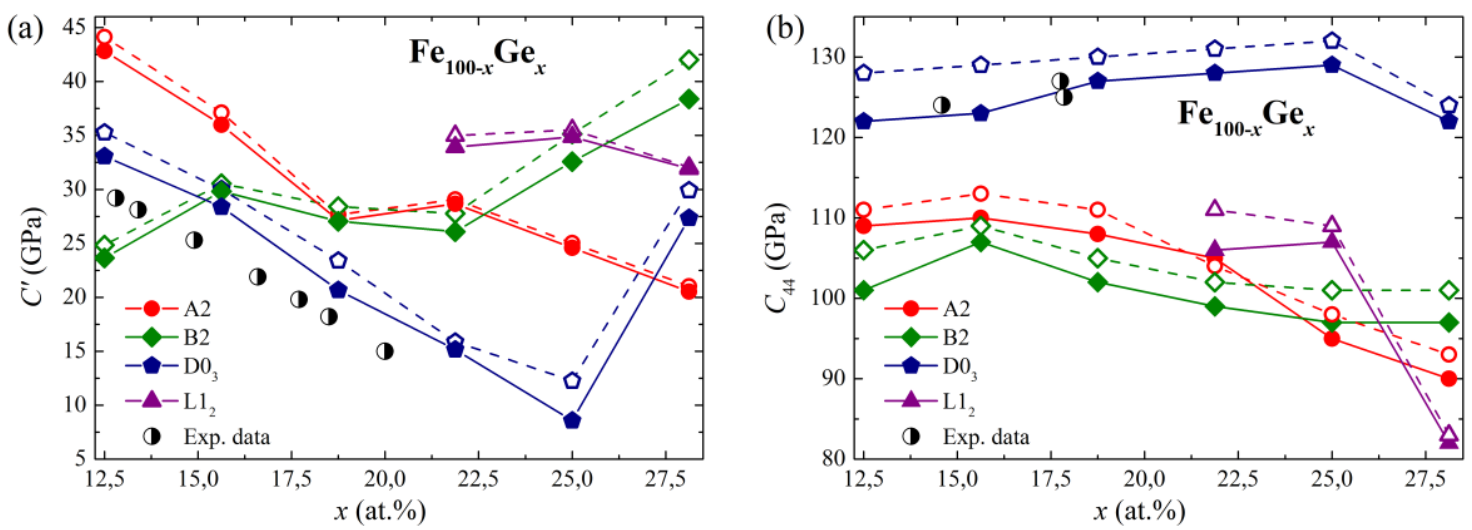

Fig. 2. Dependence of (a) tetragonal $C^{\prime}$ and (b) rhombohedral $C_{44}$ shear moduli of $\mathrm{Fe}_{100-x} \mathrm{Ge}_{x}$ alloys on $\mathrm{Ge}$ concentration, $x$. The results were obtained by two types of relaxations: electronic (filled symbols) and full ionic (open symbols). Experimental values (half-filled symbols) were taken from [1] for $C^{\prime}$ and from [14] for $C_{44}$

The concentration dependencies of tetragonal $C^{\prime}$ and rhombohedral $C_{44}$ shear moduli are presented in Fig. 2 (a, b) together with the room-temperature experimental results. For both elastic moduli, the closest to the experimental values were calculation results for the $\mathrm{D}_{3}$ structure obtained by electronic relaxation. The increase of Ge concentration up to $x=25$ at. \% leads to a decrease in the tetragonal elastic modulus. This indicates a pronounced softening of the $\mathrm{D}_{3}$ structure. The rhombohedral shear modulus $C_{44}$ does not change significantly with $x$, only slightly decrease for structures with Ge excess $\left(x>25\right.$ at. \%). The same concentration dependencies for both $C^{\prime}$ and $C_{44}$ were obtained theoretically for the $\mathrm{DO}_{3}$ phase in the $\mathrm{Fe}-\mathrm{Ga}$ system [24]. In the case of $\mathrm{A} 2$ and $\mathrm{L}_{2}$ structures, the tetragonal shear modulus decreases in the considered range of $12,5 \leq x \leq 28,125$ at.\%. For $\mathrm{A} 2, \mathrm{~B} 2$, and $\mathrm{L} 1_{2}$ structures, the rhombohedral shear modulus $C_{44}$ has a trend similar to $C^{\prime}$.

\section{Conclusion}

We have studied the structural and elastic properties of Fe-Ge alloys by using the first-principles methods. Crystal structure optimization was performed for phases A2, B2, D0 3 , and $\mathrm{L}_{2} \mathrm{Of}_{\mathrm{Fe}_{100-x} \mathrm{Ge}_{x}}$ $(12,5 \leq x \leq 28,125$ at. \%). We considered two types of relaxations: electronic and full ionic. We showed that the lattice constants increase with Ge concentration in both approaches, and the difference between obtained lattice constant, total energy, and formation energy is negligible. The $\mathrm{D}_{3}$ structure is energetically favourable for all considered Ge concentrations. The dependence of atomic volume $V_{a}(x)$ on $\mathrm{Ge}$ content corresponds to the sequence of phase transitions observed experimentally $\left(\mathrm{A} 2 \rightarrow \mathrm{B} 2 \rightarrow \mathrm{D} 0_{3}\right)$ in the range $8 \leq x \leq 22$ at. $\%$. We estimated the temperature of structural phase transitions $T_{t r}^{p h}$ as a function of Ge concentration and found that the slope of the calculated curve for the A2 phase is steeper than for the experimental one. Moreover, we obtained the dependencies of tetragonal $C^{\prime \prime}$ and rhombohedral $C_{44}$ shear 
moduli on Ge content. For $\mathrm{A} 2, \mathrm{D}_{3}$, and $\mathrm{L}_{2}$ structures the increase of $\mathrm{Ge}$ concentration leads to a decrease in the tetragonal elastic moduli. The rhombohedral shear moduli do not change significantly with $x$. In general, results obtained by electronic relaxation are in good agreement with the experimental data.

\section{Acknowledgments}

This work was supported by Russian Science Foundation grant No. 18-12-00283 (Sections 2 and 3), V. Sokolovskiy and V. Buchelnikov gratefully acknowledge the financial support of Ministry of Science and Higher Education of the Russian Federation in the framework of increase Competitiveness Program of NUST "MISIS" (Grant No. K2-2019-006), implemented by a governmental decree dated $16^{\text {th }}$ of March 2013, No 211, M. Zagrebin acknowledge the financial support of Young Scientist Support Foundations of Chelyabinsk State University.

\section{References}

1. Restorff J.B., Wun-Fogle M., Hathaway K.B., Clark A.E., Lograsso T.A., Petculescu G. Tetragonal magnetostriction and magnetoelastic coupling in $\mathrm{Fe}-\mathrm{Al}, \mathrm{Fe}-\mathrm{Ga}, \mathrm{Fe}-\mathrm{Ge}, \mathrm{Fe}-\mathrm{Si}, \mathrm{Fe}-\mathrm{Ga}-\mathrm{Al}$, and $\mathrm{Fe}-\mathrm{Ga}-$ Ge alloys. Journal of Applied Physics, 2012, Vol. 111, pp. 023905. DOI:10.1063/1.3674318

2. Clark A.E., Hathaway K.B., Wun-Fogle M., Restorff J.B., Lograsso T.A., Keppens V.M., Petculescu G., Taylor R.A. Extraordinary magnetoelasticity and lattice softening in bcc Fe-Ga alloys. Journal of Applied Physics, 2003, Vol. 93, Iss. 10, pp. 8621-8623. DOI:10.1063/1.1540130

3. Turtelli R.S., Nunesa C.B., Teixeira L.C., Grössinger R., Suzuki P.A., Barbatti C. Magnetostriction of polycrystalline Fe-Ge alloys. Journal of Alloys and Compounds, 2009, Vol. 471, Iss. 1-2, pp. 52-55. DOI:10.1016/j.jallcom.2008.03.038

4. Ikeda O., Kainuma R., Ohnuma I., Fukamichi K., Ishida K. Phase equilibria and stability of ordered b.c.c. phases in the Fe-rich portion of the Fe-Ga system. Journal of Alloys and Compounds, 2002, Vol. 347, Iss. 1-2, pp. 198-205. DOI:10.1016/S0925-8388(02)00791-0

5. Enoki H., Ishida K., Nishizawa T. Miscibility gap due to ordering in the bcc Fe-Ge system. Metallurgical transactions A, 1987, Vol. 18A, pp. 949-955. DOI:10.1007/BF02668543

6. Chessin H., Arajs S., Colvin R.V., Miller D.S. Paramagnetism and lattice parameters of Iron-rich iron-germanium alloys. Journal of Physics and Chemistry of Solids, 1963, Vol. 24, Iss. 2, pp. 261-273. DOI:10.1016/0022-3697(63)90131-8

7. Golovin I.S., Ivleva T.V., Jäger S., Jencus P., Neuhäuser H., Redfern S.A.T., Siemers C. Structure and anelasticity of Fe-Ge alloys. Solid State Phenomena, 2008, Vol. 137, pp. 59-68. DOI:10.4028/www.scientific.net/SSP.137.59

8. Golovin I.S., Jäger S., Mennerich Chr., Siemers C., Neuhäuser H. Structure and anelasticity of Fe3Ge alloy. Intermetallics, 2007, Vol. 15, Iss. 12, pp. 1548-1557. DOI:10.1016/j.intermet.2007.06.004

9. Konygin G.N., Yelsukov E.P., Porsev V.E. The structure and magnetic properties of the nonequilibrium $\mathrm{Fe}_{100-x} \mathrm{Ge}_{x}$ ( $x=5-40$ at\%) system produced by mechanical alloying. Journal of Magnetism and Magnetic Materials, 2005, Vol. 288, pp. 27-36. DOI:10.1016/j.jmmm.2004.07.052

10. Cabrera A.F., Sánchez F.H. Mössbauer study of ball-milled Fe-Ge alloys. Phys. Rev. B, 2002, Vol. 65, pp. 094202. DOI: 10.1103/PhysRevB.65.094202

11. Kanematsu K., Ohoyama T. Magnetic and X-ray studies of iron-germanium system II. Phase diagram and magnetism of each phase. Journal of the Physical Society of Japan, 1965, Vol. 20, pp. 236242. DOI:10.1143/JPSJ.20.236

12. Sarkar S., Bansal C., Chatterjee A. Gibbs-Thomson effect in nanocrystalline Fe-Ge. Phys. Rev. B, 2000, Vol. 62, pp. 3218-3222. DOI: 10.1103/PhysRevB.62.3218

13. Belamri Z., Hamana D., Golovin I.S. Study of order-disorder transitions in Fe-Ge alloys and related anelastic phenomena. Journal of Alloys and Compounds, 2013, Vol. 554, pp. 348-356. DOI: $10.1016 /$ j.jallcom.2012.11.012

14. Petculescu G., LeBlanc J.B., Wun-Fogle M., Restorff J.B., Yuhasz W.M., Lograsso T.A., Clark A.E. Magnetoelastic coupling in $\mathrm{Fe}_{100-x} \mathrm{Ge}_{x}$ single crystals with $4<x<18$. Journal of Applied Physics, 2009, Vol. 105, p. 07A932. DOI: 10.1063/1.3061864

15. Matyunina M.V., Zagrebin M.A., Sokolovskiy V.V., Buchelnikov V.D. The structural Phase Diagrams of Fe-Y (Y=Ga, Ge, Al) alloys. Materials Research Proceedings, 2018, Vol. 9, pp. 162-166. DOI: $10.21741 / 9781644900017-31$ 


\section{Физика}

16. Khmelevska T., Khmelevskyi S., Ruban A.V., Mohn P. Magnetism and origin of nonmonotonous concentration dependence of the bulk modulus in Fe-rich alloys with $\mathrm{Si}$, Ge and $\mathrm{Sn}$ : a firstprinciples study. Journal of Physics: Condensed Matter, 2006, Vol. 18, no. 29, pp. 6677-6689. DOI: $10.1088 / 0953-8984 / 18 / 29 / 009$

17. Zagrebin M.A., Matyunina M.V., Sokolovskiy V.V., Buchelnikov V.D. the effect of exchangecorrelation potentials on magnetic properties of $\mathrm{Fe}-(\mathrm{Ga}, \mathrm{Ge}, \mathrm{Al})$ alloys. Journal of Physics: Conference Series, 2019, Vol. 1389, VII Euro-Asian Symposium "Trends in Magnetism", 8-13 September 2019, Ekaterinburg, Russian Federation, pp. 012087. DOI: 10.1088/1742-6596/1389/1/012087

18. Matyunina M.V., Zagrebin M.A., Sokolovskiy V.V., Buchelnikov V.D. First principles study of structural and magnetic properties in $\mathrm{Fe}_{100-x} \mathrm{Ge}_{x}$ alloys. Physica B: Condensed Matter, 2020, Vol. 580, pp. 411934. DOI:10.1016/j.physb.2019.411934

19. Cao J.X., Zhang Y.N., Ouyang W.J., Wu R.Q. Large magnetostriction of $\mathrm{Fe}_{1-x} \mathrm{Ge}_{x}$ and its electronic origin: Density functional study. Physical Review B, 2009, Vol. 80, Iss. 10, p. 104414. DOI:10.1103/PhysRevB.80.104414

20. Kresse G., Joubert D. From ultrasoft pseudopotentials to the projector augmented-wave method Phys. Rev. B, 1999, Vol. 59, Iss. 3, pp. 1758. DOI: 10.1103/PhysRevB.59.1758

21. Kresse G., Furthmüller J. Efficient iterative schemes for ab initio total-energy calculations using a plane-wave basis set. Physical Review B, 1996, Vol. 54, Iss. 16, pp. 11169-11186. DOI:10.1103/PhysRevB.54.11169

22. Perdew J.P., Burke K., Ernzerhof M. Generalized gradient approximation made simple. Phys. Rev. Lett., 1996, Vol. 77, Iss. 18, pp. 3865-3868. DOI: 10.1103/PhysRevLett.77.3865

23. Monkhorst H.J., Pack J.D. Special points for Brillouin-zone integrations. Physical Review B, 1976, Vol. 13, Iss. 12, pp. 5188-5192. DOI: 10.1103/physrevb.13.5188

24. Matyunina M.V., Zagrebin M.A., Sokolovskiy V.V., Pavlukhina O.O., Buchelnikov V.D., Balagurov A.M., Golovin I. S. Phase diagram of magnetostrictive Fe-Ga alloys: insights from theory and experiment. Phase Transitions, 2019, Vol. 92, Iss. 2, pp. 101-116. DOI: $10.1080 / 01411594.2018 .1556268$

25. Warren B.E. X-ray diffraction. New York (NY), Dover Publications, 1990, 400 p.

26. Balagurov A.M., Bobrikov I.A., Sumnikov S.V., Golovin I.S. Dispersed clusters in $(\mathrm{Fe}, \mathrm{Cr})_{3} \mathrm{Al}$ alloys: Neutron time-of-flight diffraction study. Physical Review Materials, 2019, Vol. 3, Iss. 1, pp. 013608. DOI: 10.1103/physrevmaterials.3.013608

27. Balagurov A.M., Samoylova N.Yu., Bobrikov I.A., Sumnikova S.V., Golovin I.S. The first- and second-order isothermal phase transitions in $\mathrm{Fe}_{3} \mathrm{Ga}$-type compounds. Acta Crystallographica, 2019, Vol. B75, pp. 1-10. DOI: 10.1107/S2052520619013106

28. Fernandez A., Tejedor L., Bru L. Electron microscopy study of phase change $\mathrm{DO}_{19} \rightarrow \mathrm{L} 1_{2}$ in the $\mathrm{Fe}_{3} \mathrm{Ge}$ compound. Physica Status Solidi (a), 1976, Vol. 34, p. K17. DOI: 10.1002/pssa.2210340147

29. Chen Q.Z., Ngan A.H.W., Duggan B.J. The L12 $\leftrightarrow$ D019 transformation in the intermetallic compound $\mathrm{Fe}_{3} \mathrm{Ge}$. Journal of Materials Science, 1998, Vol. 33, P. 5405-5414. DOI: $10.1023 / \mathrm{A}: 1004454402007$

Received March 16, 2020 
Bulletin of the South Ural State University Series "Mathematics. Mechanics. Physics" 2020, vol. 12, no. 2, pp. 49-56

\title{
СТРУКТУРНЫЕ И УПРУГИЕ СВОЙСТВА СПЛАВОВ FE-GE: ИССЛЕДОВАНИЯ АВ INITIO
}

\author{
М.А. Загребин, ${ }^{1,2}$ М.В. Матюнина', В.В. Соколовский ${ }^{1,3}$, В.Д. Бучельников ${ }^{1,3}$ \\ 1 Челябинский государственный университет, г. Челябинск, Российская Федерация \\ 2 Южно-Уральский государственный университет, г. Челябинск, Российская Федерация \\ ${ }^{3}$ Национальный исследовательский технологический университет «МИСиС», г. Москва, Рос- \\ сийская Федерация \\ E-mail: matunins.fam@mail.ru
}

В работе представлены исследования структурных и упругих свойств фаз $\mathrm{A} 2, \mathrm{~B} 2, \mathrm{D}_{3}$ и $\mathrm{L}_{2}$ сплавов $\mathrm{Fe}_{100-x} \mathrm{Ge}_{x}(12,5 \leq x \leq 28,125$ ат. \%), выполненные при помощи теории функционала плотности. Кристаллические структуры исследовались при помощи двух типов релаксаций: электронной и полной ионной. Построены концентрационные зависимости атомных объемов, температур структурных фазовых переходов, тетрагональных и ромбоэдрических модулей сдвига. Кривые зависимостей величин атомного объема соответствует последовательности фазовых переходов, наблюдаемых экспериментально: $\mathrm{A} 2 \rightarrow \mathrm{B} 2 \rightarrow \mathrm{D0}_{3}(x \leq 22$ ат. \% содержания $\mathrm{Ge})$. Показано, что температуры структурных фазовых переходов возрастают с увеличением концентрации $\mathrm{Ge}$. B соответствии с экспериментальными результатами рассчитанные тетрагональные модули для структур $\mathrm{D}_{3}, \mathrm{~A} 2$ и $\mathrm{L}_{2}$ уменьшаются с ростом атомов $\mathrm{Ge}$ в сплавах. Величина ромбоэдрического модуля сдвига существенно не изменяется с увеличением числа атомов $\mathrm{Ge} . C_{44}$ увеличивается для фазы $\mathrm{D}_{3}$, в то время как для $\mathrm{A} 2, \mathrm{~B} 2$ и $\mathrm{L1}_{2}$ уменьшается.

Ключевые слова: ab initio; кристаллическая структура; фазовые превращения; упругие модули.

\section{Литература}

1. Tetragonal magnetostriction and magnetoelastic coupling in $\mathrm{Fe}-\mathrm{Al}, \mathrm{Fe}-\mathrm{Ga}, \mathrm{Fe}-\mathrm{Ge}, \mathrm{Fe}-\mathrm{Si}, \mathrm{Fe}-\mathrm{Ga}-$ Al, and Fe-Ga-Ge alloys / J.B. Restorff, M. Wun-Fogle, K.B. Hathaway et al. // J. of Applied Physics. 2012. - Vol. 111. - P. 023905.

2. Clark, A.E. Extraordinary magnetoelasticity and lattice softening in bcc Fe-Ga alloys / A.E. Clark, K.B. Hathaway, M. Wun-Fogle et al. // J. of Applied Physics. - 2003. - Vol. 93, Iss. 10. P. 8621-8623.

3. Magnetostriction of polycrystalline Fe-Ge alloys / R.S. Turtelli, C.B. Nunesa, L.C. Teixeira et al. // Journal of Alloys and Compounds. - 2009. - Vol. 471, Iss. 1-2. - pp. 52-55.

4. Ikeda, O. Phase equilibria and stability of ordered b.c.c. phases in the Fe-rich portion of the FeGa system / O. Ikeda, R. Kainuma, I. Ohnuma et al. // J. of Alloys and Compounds. - 2002. - Vol. 347, Iss. 1-2. - P. 198-205.

5. Enoki, H. Miscibility gap due to ordering in the bcc Fe-Ge system / H. Enoki, K. Ishida, T. Nishizawa // Metallurgical Transactions A. - 1987. - Vol. 18A. - P. 949-955.

6. Paramagnetism and lattice parameters of Iron-rich iron-germanium alloys / H. Chessin, S. Arajs, R.V. Colvin, D.S. Miller // J. of Physics and Chemistry of Solids. - 1963. - Vol. 24, Iss. 2. - P. 261273.

7. Golovin, I.S. Structure and anelasticity of Fe-Ge alloys / I.S. Golovin, T.V. Ivleva, S. Jäger et al. // Solid State Phenomena. - 2008. - Vol. 137. - P. 59-68.

8. Golovin, I.S. Structure and anelasticity of $\mathrm{Fe}_{3} \mathrm{Ge}$ alloy / I.S. Golovin, S. Jäger, Chr. Mennerich et al. // Intermetallics. - 2007. - Vol. 15. - P. 1548-1557.

9. Konygin, G.N. The structure and magnetic properties of the non-equilibrium $\mathrm{Fe}_{100-x} \mathrm{Ge}_{x}(x=5-40$ at\%) system produced by mechanical alloying / G.N. Konygin, E.P. Yelsukov, V.E. Porsev // J. of Magnetism and Magnetic Materials. - 2005. - Vol. 288. - P. 27-36. 


\section{Физика}

10. Cabrera, A.F. Mössbauer study of ball-milled Fe-Ge alloys / A.F. Cabrera, F.H. Sánchez // Physical Review B. - 2002. - Vol. 65. - P. 094202.

11. Kanematsu, K. Magnetic and X-ray studies of iron-germanium system II. Phase diagram and magnetism of each phase / K. Kanematsu, T. Ohoyama // J. of the Physical Society of Japan. - 1965. Vol. 20. - P. 236-242.

12. Sarkar, S. Gibbs-Thomson effect in nanocrystalline Fe-Ge / S. Sarkar, C. Bansal, A. Chatterjee // Physical Review B. - 2000. - Vol. 62. - P. 3218-3222.

13. Belamri, Z. Study of order - disorder transitions in Fe-Ge alloys and related anelastic phenomena / Z. Belamri, D. Hamana, I.S. Golovin // J. of Alloys and Compounds. - 2013. - Vol. 554. - P. 348 356.

14. Petculescu, G. Magnetoelastic coupling in $\mathrm{Fe}_{100-x} \mathrm{Ge}_{x}$ single crystals with $4<x<18$ / G. Petculescu, J.B. LeBlanc, M. Wun-Fogle et al. // J. of Applied Physics. - 2009. - Vol. 105. - 07A932.

15. The structural Phase Diagrams of $\mathrm{Fe}-\mathrm{Y}(\mathrm{Y}=\mathrm{Ga}, \mathrm{Ge}, \mathrm{Al})$ alloys / M.V. Matyunina, M.A. Zagrebin, V.V. Sokolovskiy, V.D. Buchelnikov // Materials Research Proceedings. - 2018. - Vol. 9. P. 162-166.

16. Magnetism and origin of non-monotonous concentration dependence of the bulk modulus in $\mathrm{Fe}$ rich alloys with Si, Ge and Sn: a first-principles study/ T. Khmelevska, S. Khmelevskyi, A.V. Ruban, P. Mohn // J. of Physics: Condensed Matter. - 2006. - Vol. 18, no. 29. - P. 6677-6689.

17. The effect of exchange-correlation potentials on magnetic properties of $\mathrm{Fe}-(\mathrm{Ga}, \mathrm{Ge}, \mathrm{Al})$ alloys / M.A. Zagrebin, M.V. Matyunina, V.V. Sokolovskiy, V.D. Buchelnikov // J. of Physics: Conference Series. $-2019 .-$ Vol. 1389. - P. 012087.

18. First principles study of structural and magnetic properties in $\mathrm{Fe}_{100-x} \mathrm{Ge}_{x}$ alloys / M.V. Matyunina, M.A. Zagrebin, V.V. Sokolovskiy, V.D. Buchelnikov // Physica B: Condensed Matter. 2020. - Vol. 580. - P. 411934

19. Large magnetostriction of $\mathrm{Fe}_{1-x} \mathrm{Ge}_{x}$ and its electronic origin: Density functional study / J.X. Cao, Y.N. Zhang, W.J. Ouyang, R.Q. Wu // Physical Review B. - 2009. - Vol. 80, Iss. 10. - P. 104414.

20. Kresse, G. From ultrasoft pseudopotentials to the projector augmented-wave method / G. Kresse, D. Joubert // Physical Review B. - 1999. - Vol. 59, Iss. 3. - P. 1758.

21. Kresse, G. Efficient iterative schemes for ab-initio total-energy calculations using a plane-wave basis set /G. Kresse, J. Furthmüller // Physical Review B. - 1996. - Vol. 54, Iss. 16. - P. 11169-11186.

22. Perdew, J.P. Generalized Gradient Approximation Made Simple / J.P. Perdew, K. Burke, M. Ernzerhof // Physical Review Letters. - 1997. - Vol. 78, Iss. 18. - P. 1396.

23. Monkhorst, H.J. Special points for Brillouin-zone integrations / H.J. Monkhorst, J.D. Pack // Physical Review B. - 1976. - Vol. 13, Iss. 12. - P. 5188-5192.

24. Phase diagram of magnetostrictive $\mathrm{Fe}-\mathrm{Ga}$ alloys: insights from theory and experiment / M.V. Matyunina, M.A. Zagrebin, V.V. Sokolovskiy et al. // Phase Transitions. - 2019. - Vol. 92, Iss. 2. - P. 101-116.

25. Warren, B.E. X-ray diffraction / B.E. Warren. - New York: Dover Publications, 1990. - 400 p.

26. Dispersed clusters in $(\mathrm{Fe}, \mathrm{Cr})_{3} \mathrm{Al}$ alloys: Neutron time-of-flight diffraction study / A.M. Balagurov, I.A. Bobrikov, S.V. Sumnikov, I.S. Golovin // Physical Review Materials. - 2019. - Vol. 3, Iss. 1. - P. 013608.

27. Balagurov, A.M. The first- and second-order isothermal phase transitions in $\mathrm{Fe}_{3} \mathrm{Ga}$-type compounds / A.M. Balagurov, N.Yu. Samoylova, I.A. Bobrikov, S.V. Sumnikova, I.S. Golovin // Acta Crystallographica Section B: Structural Science, Crystal Engineering and Materials. - 2019. - Vol. B75. - P. 1-10.

28. Fernandez, A. Electron microscopy study of phase change $\mathrm{DO}_{19} \rightarrow \mathrm{L}_{2}$ in the $\mathrm{Fe}_{3} \mathrm{Ge}$ compound / A. Fernandez, L. Tejedor, L. Bru // Physica Status Solidi (a). - 1976. - Vol. 34. - P. K17.

29. Chen, Q.Z. The L12↔D019 transformation in the intermetallic compound $\mathrm{Fe}_{3} \mathrm{Ge} / \mathrm{Q} . Z$. Chen, A.H.W. Ngan, B.J. Duggan // J. of Materials Science. - 1998. - Vol. 33. - P. 5405-5414.

Поступила в редакцию 16 марта 2020 2. 